\title{
A Conceptual Model of Green Supply Chain Management Effects on Firm Performance
}

\author{
Reza Hidayat, Omia Crefioza, Pajar Damar Kusuma, Yusuf Syahiir Habiibii, Rafida Nur Fitria, \\ Fauzia Damas Nungkiastuti, and Fahmi Rezqa Afifi \\ Faculty of Economics and Business, Diponegoro University, Semarang \\ e-mail: rezalumaksono@gmail.com
}

\begin{abstract}
Green supply chain management (GSCM) is one of the strategies to overcome environmental problems caused by industrial activities and pressure from stakeholders such as the government and customers. The concept of green supply chain is a multidisciplinary issue that emerges essentially from building environment-friendly management practices in the context of supply chains. Nowadays manufacturing moves to Asia, awareness of green operations or sustainability has become important but relevant studies in Asian countries are not many especially in the Southeast Asia region .Prior studiesabout effects of GSCM on firm performance suggested for more indepth research on the effect of each GSCM practices on company performance because GSCM's scope is quite extensive. Furthermore, several studies that examine the relationships between GSCM practices and organizational performance, there is a dearth of studies that have considered these relationships within the context of organizational or business strategy. Most studies have examined the outcomes of GSCM within the context of tangible measures such as environmental, operational, and economic performance. Consequently, research on intangible outcomes of GSCM practices is limited. Thus, the need examines the deployment of GSCMand analyzes their impact on environmental, economic and intangible performance.
\end{abstract}

Keywords - Manufacture industry, GSCM, Performance.

\section{INTRODUCTION}

$\mathrm{I}$ NTEGRATION between the environment and supply chain activities is called green supply chain management (GSCM) or green supply chain management. Green supply chain management (GSCM) can also be used as a strategy for development that has a nature of sustainability in competitive markets, with the aim of achieving financial benefits, reducing environmental risks, and improving the company's image. The addition of the green component to the supply chain has the meaning that all processes from the initial input or raw goods into output or products which in each process always include aspects of environmental balance. The implementation of green supply chain management is similar to supply chain management in general, which in its implementation must also integrate with the company's goals (Srivastava, 2007).

The concept of a green supply chain (green supply chain) is a multidisciplinary problem that basically arises from the application of environmentally friendly management in the context of the supply chain (Sezen, 2019). Green supply chain management is built with ideas that incorporate thinking environmental issues into the supply chain cycle. Items included in ideas that include environmental thinking such as product design, supplier selection and material sourcing, manufacturing processes, product packaging, product delivery to consumers, and final product management after use (Younis, Sundarakani, \& Vel, 2016).

The manufacturing industry is one of the industries that contributes the most waste (Laosirihongthong \& Tan, 2013). This waste is very dangerous if not dealt with immediately because it can cause environmental degradation, where environmental degradation itself can harm the community but also threaten the resources of the company itself. In implementing green supply chain management it cannot be done by only one party, but the whole in the supply chain chain.

At present manufacturing has begun to move into the Asian region, so awareness of environmentally friendly operations and sustainability of resources are noteworthy but relevant studies in Asian countries are lacking (Laosirihongthong \& Tan, 2013). Specifically, in the Southeast Asian context, if green supply chain management is to be applied broadly, the relationship between practice and performance needs to be identified and therefore more research on green supply chain management in sub-regions (Rao, 2002; Rao and Holt, 2005).

Green supply chain management (GSCM) has a variety of process so further research needs to be done on each process of green supply chain management (Younis et al., 2016). According to Srivastava (2007) green supply chain management (GSCM) can be interpreted as the inclusion of environmental thoughts into the entire supply chain chain from raw materials to products to products to consumers. The statement is in line with research conducted by Sundarakani et al (2010) which states that green supply chain management (GSCM) is a series of supply chains integrated with environmental thinking consisting of product design, supplier selection and source of materials, manufacturing processes, product packaging, product shipping to consumers, and end of life management. In the process of implementing green supply chain management (GSCM) it deals with stakeholders such as suppliers and customers (Laosirihongthong \& Tan, 2013). Therefore we need environmental cooperation between companies and suppliers and customers in the process of implementing green supply chain management (GSCM).

Previous research also found different results between each veriable of green supply chain management and firm performance. In his further research, Sazen (2019) found that green purchasing had no effect on company performance. In 
contrast to Younis (2016) who found the results that green purchasing can improve economic performance.

The expected outcome of implementing green supply chain management (GSCM) is to be able to improve company performance, whether tangible or intangible. However, most studies only discuss the results of green supply chain management (GSCM) in tangible contexts such as economic performance, operational performance, or environmental performance. As a result, research on intangible contents is very limited. As the results of research conducted by Laari et al (2015), which states that the majority process of green supply chain management has a positive effect on company performance.

This study makes a significant contribution to ongoing research on the relationship of environmentally friendly practices and performance results by including a different set of results in the context of business strategy. In addition, data were collected from developing countries with an increasing global business presence but very little research on green supply chain management (GSCM) has been carried out especially in countries in the Asian region, especially in Southeast Asia (Laosirihongthong \& Tan, 2013).

\section{LITERATURE REVIEW}

\section{A. GSCM Practices}

The GSCM practices needs to be integrated throughout the supply chain including the acquisition of raw materials, product design, manufacturing processes, shipping of finished products and finally the management of product disposal after its useful life (Srivasta, 2007). In addition, the company adopted green supply chain management (GSCM) practices in response to stakeholder demands such as regulation from the government for environmentally friendly products and processes (Jr., Zelbst, Meacham, \& Bhadauria, 2012)..Hence, this conceptual will be used green purchasing, eco-design, reverse logistic, and legislation and regulatory.

\section{1) Green purchasing}

Green purchasing can be defined as an environmental purchasing initiative that aims to ensure the products and materials purchased meet the environmental goals set by the purchasing company such as reducing sources of waste, encouraging recycling, reusing and replacing materials (Carter et al., 1998; Min and Galle, 2001; Zsidisin and Siferd, 2001). Green purchasing has received significant attention throughout the world and businesses are keen to evaluate the environmental performance of their suppliers before making any procurement decisions (Zhu and Sarkis, 2006). Some authors go beyond that to consider evaluating the environmental performance of second-level suppliers as well. For example Walton et al. (1998), second-tier supplier environmental performance as a second important evaluation criterion in terms of evaluating the supplier's environmental performance. Furthermore, Green et al. (1998), found that implementing environmentally friendly purchasing practices in companies in the UK could help companies achieve "environmental excellence". In the same context, Schlegelmilch et al. (1996) found that environmental awareness has a positive impact on pro-environment purchasing behavior.

\section{2) Eco-design.}

Eco-design is an important green supply chain initiative because at this stage every aspect of the product is determined including the type of raw materials to be used, energy consumed, and waste generated. It can be said that product design touches every stage in the supply chain when it concerns environmental impacts, from production to consumption and finally disposal. Therefore it is very important to integrate environmental aspects in product design from an initial stage (Eltayeb, 2010).

\section{3) Reverse logistics}

Reverse logistics can be defined as the return or retrieval of products and materials from the point of consumption to the front of the supply chain for the purpose of recycling, reuse, remanufacturing, repair, repair or disposal of products and materials safely (Younis et al., 2016). Like the other GSCM practices, logistics has turned out to play an important role in increasing the operational efficiency of an organization, increasing its competitiveness and reducing broad system costs. Reverse logistics is one of the most commonly used GSCM practices in extant literature.

\section{4) Legislation and regulatory practices}

Hitchcock (2012) noted that legislation and regulatory practices are manifested in different ways such as PPW in 2004, WEEE and RoHS in 2003, and EUP in 2005. Lu et al. (2007) noted that many organizations are making efforts to accelerate the greening of their supply chain in response to stringent legislation and regulation. These efforts include proactively addressing environmental and social concerns in advance of regulation (Zailani et al., 2012).

\section{B. Firm Performance}

In this study, the assessment of company performance is not only in terms of a company's finances, but in terms of environmental performance and intangible performance. This was also supported by Zhu et al. (2008) and (Zacharia et al., 2009) which state that the financial and non-financial performance of an organization is the result of applying GSCM practices.

\section{1) Environmental performance}

Direct environmental impacts come from inputs from firstlevel suppliers that increase waste during product storage, transportation, processing, use or disposal. The environmental impact is not directly connected to the company's second-level supplier products, which produce inputs used in the production process of the first-level supplier. Defined in the ISO 14001 certificate, environmental impact is any change in the environment, whether adverse or beneficial, in whole or in part resulting from the organization's activities, products, or services (Laari et al., 2015). So in his research (Sezen, 2019) measures the assessment of environmental performance through reducing the consumption of hazardous substances in production, reducing energy consumption, reducing waste (water, solid, or gas), and reducing the frequency of environmental accidents. 


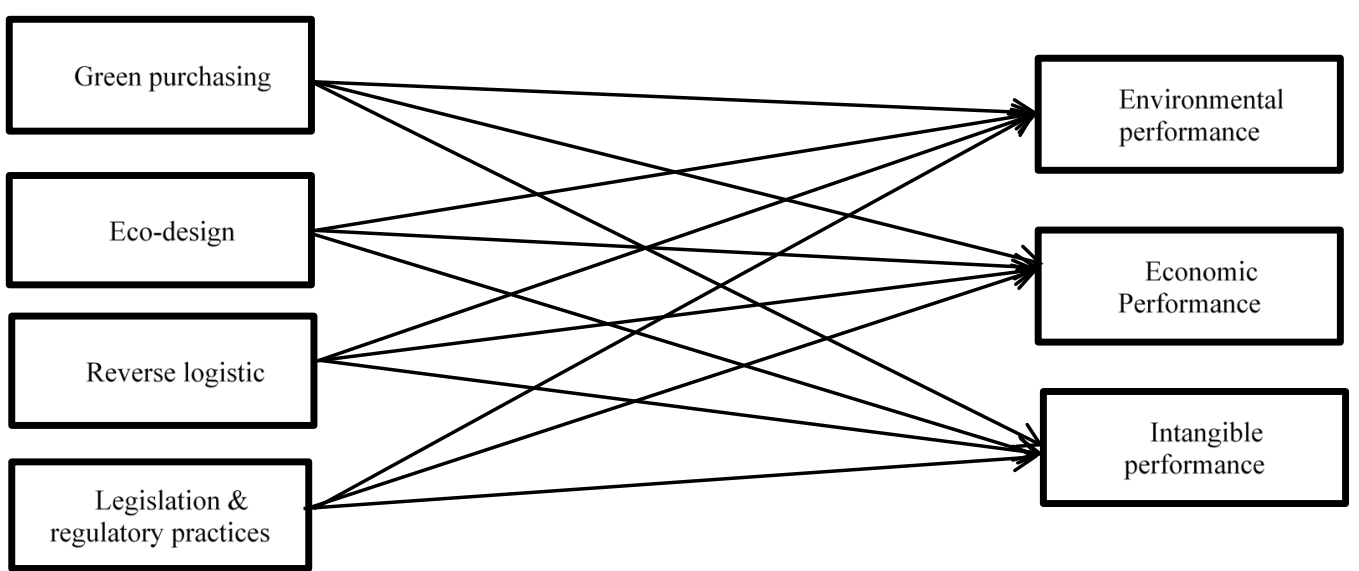

Figure 1. Research Framework.

\section{2) Economic performance}

Financial performance measures determine the long-term goals of business units (Kaplan \& Norton 1996). Stock et al. (2000) argue that compared to operational performance measures, financial performance measures are more likely to reflect company valuations by factors outside the company's boundaries. To measure the economic performance of manufacturing companies can be seen based on a decrease in production costs, an increase in the level of profitability in general companies, and a decrease in the cost of raw materials or components (Laosirihongthong \& Tan, 2013).

\section{3) Intangible performance}

In intangible performance the value to be measured is in terms of product image, loyalty and customer satisfaction and company image with suppliers, customers and employees.

\section{RESEARCH FRAMEWORK AND HYPOTHESES}

As seen in the system modeling according to Figure 1, it The authors believe that the implementation of GSCM practices and their potential impacts on the outcome variable may be influenced by organizational strategy. Economic performance is related to the plant's ability to reduce costs associated with purchased materials, energy consumption, waste treatment, waste disposal, and fines for environmental accidents (Zhu et al., 2008). This study also includes elements such as profitability and sales. One of the most controversial issues related to GSCM is whether green operations have costs for business (Hart and Ahuja, 1996). But there are those who argue that GSCM will positively influence the economic performance of businesses. For example, NRBV refers to the idea that environmental practices will provide significant benefits for businesses. In general, it is mentioned in the literature that GSCM can improve economic performance in two ways (Hart, 1995). First, businesses can get direct economic benefits by reducing waste and energy costs. Second, businesses can benefit economically from more indirect ways by increasing the loyalty and reputation of their companies through environmentally friendly practices (Sezen, 2019).

GSCM practices include every effort to reduce the adverse effects of the company's products or services on the environment. These efforts have a positive impact on improving environmental performance by reducing the consumption of solid / liquid waste and hazardous substances, reducing the incidence of environmental accidents and improving public health (Sezen, 2019). In their research, Azevedo et al. (2011) states that green practices contribute to improving environmental performance by reducing waste caused by business. In short, research shows that green activities have a positive impact on environmental performance through practices such as reducing waste production and the use of energy and materials (Sezen, 2019).

According to Laosirihongthong \& Tan (2013), environmentally friendly product design shows the effective use of materials and reduction of waste. Waste reduction can lead to better costs for the organization and better use of materials can have a positive impact on environmental performance while products that are designed to be environmentally friendly can improve brand image. Similar arguments apply to the design of environmentally friendly packaging that is characterized by packaging that can be reused and recycled, minimizing waste by reducing packaging and reducing or eliminating hazardous materials in the packaging (Sezen, 2019).

Based on the explanation above, a research framework and related hypotheses can be made shown in Figure 1.

The adoption of green purchasing in green supply chain initiatives to test their impact on a series of company performance results including environmental, economic and intangible performance (Laosirihongthong \& Tan, 2013). Sezen (2019) examines the impact of green purchases together with internal environmental management, green information systems, collaboration with customers, investment recovery and environmentally friendly design, on various company performance. This includes environmental, operational, economic and organizational performance.

Base on the discussion above, it is therefore proposed that:

1. There is a positive relationship between the implementation of Green Purchasing practices and corporate environmental performance.

2. There is a positive relationship between the implementation of Green Purchasing practices and corporate economic performance.

3. There is a positive relationship between the implementation of Green Purchasing practices and corporate intangible performance. 
Perotti et al. (2012) used semi-structured interviews with executives from 13 third-party logistics providers (3PL) in Italy to discover how eco-design together with other GSCM practices could affect company performance. Similar with Diabat et al. (2013), who explored the relationship between a set of GSCM practices (including eco-design) and different performance outcomes. Eco-design practices are evidence of effective material use and waste reduction. Waste reduction can lead to better costs for the organization and better use of materials can have a positive impact on environmental performance while products that are designed to be environmentally friendly can improve brand image. A similar argument applies to the design of environmentally friendly packaging which is characterized by packaging that can be reused and recycled, minimizing waste by reducing packaging and reducing or eliminating hazardous materials in the packaging (Sezen, 2019). Hence, base on the discussion above, it is therefore proposed:

1. There is a positive relationship between implementation of Eco-design practices and the corporate environmental performance.

2. There is a positive relationship between implementation of Eco-design practices and the corporate economic performance.

3. There is a positive relationship between implementation of Eco-design practices and the corporate intangible performance.

Reverse logistics is one of the most commonly used GSCM practices in extant literature. For example, Perotti et al. (2012), included reverse logistics together with other GSCM initiatives in their study of several logistics providers in Italy to assess the level of adoption of these initiatives and their potential impact on different dimensions of company performance. Likewise Younis et al. (2016) which examines reverse logistic in manufacturing companies in the UAE using the mix method. Hence, base on the discussion above, it is therefore proposed:

1. There is a positive relationship between implementation of Reverse Logistic practices and the corporate environmental performance.

2. There is a positive relationship between implementation of Reverse Logistic practices and the corporate economic performance.

3. There is a positive relationship between implementation of Reverse Logistic practices and the corporate intangible performance.

Regulatory practices typically involve the reduction or elimination of hazardous materials in products and packaging and well as the adoption of recycling, reuse and environmentally-friendly disposal ( $\mathrm{Lu}$ et al., 2007; Hitchcock, 2012) and these can all impact cost, company/brand image and the environment. Hence, base on the discussion above, it is therefore proposed:

1. There is a positive relationship between implementation of Legislation and Regulatory practices and the corporate environmental performance.

2. There is a positive relationship between implementation of Legislation and Regulatory practices and the corporate economic performance.
There is a positive relationship between implementation of Legislation and Regulatory practices and the corporate intangible performance.

\section{CONCLUSION}

Much research has been done on the effect of GSCM on company performance, but not much in the Asian region especially Southeast Asia. The result from previous studies there wasn't consensus because the differences in the influence of each process of GSCM practice on company performance. This paper proposed more in-depth research about the effect of GSCM practices on company performance.

The subject launches a number of challenges for managers, academics and researchers. GSCM involves a paradigm shift in which the issue of sustainability is no longer seen as a source of costs, representing a potential source of competitive advantage for companies. Manufactures today are under pressure to adopt these strategies to create an environmental stance that is a driver for reduced costs and risks, increased revenues, and improved brand image. Organizations which have taken up the environmental position go beyond the basics of cutting waste and operating efficiently to adopt the strategy of Lean and Clean to be really green.

\section{REFERENCES}

[1]. Azevedo, S.G., Carvalho, H. and Machado, V.C. (2011), "The influence of green practices on supply chain performance: a case study approach", Transportation Research Part E: Logistics and Transportation Review, Vol. 47 No. 6, pp. 850-871.

[2]. Carter, C.R. and Carter, J.R. (1998), "Inter-organizational determinants of environmental purchasing: initial evidence from the consumer products industries", Decision Sciences, Vol. 29 No. 3, pp. 659-684.

[3]. Carter, C.R. and Ellram, L.M. (1998), "Reverse logistics: a review of the literature and framework for future investigation", Journal of Business Logistics, Vol. 19 No. 1, pp. 85-102.

[4]. Diabat, A., Khodaverdi, R. and Olfat, L. (2013) "An exploration of green supply chain practices and performance in an automotive industry", International Journal of Advanced Manufacturing Technology, Vol. 68, pp. 949-961.

[5]. Eltayeb, T., Zailani, S. and Jayaraman, K. (2010) "The examination on the drivers for green purchasing adoption among EMS 14001 certified companies in Malaysia", Journal of Manufacturing Technology Management, Vol. 21, Iss. 2, pp. 206 - 225.

[6]. Eltayeb, T., Zailani, S., and Ramayah, T. (2011) "Green supply chain initiatives among certified companies in Malaysia and environmental sustainability: Investigating the outcomes", Resources Conservation and Recycling, Vol. 55, Iss. 5, pp. 495-506.

[7]. Green, K.W., Zelbst, P.J., Meacham, J. and Bhadauria, V.S. (2012) "Green supply chain management practices: impact on performance", Supply Chain Management: An International Journal, Vol. 17 No. 3, pp. 290-305.

[8]. Hart, S.L. (1995), "A natural resource based view of the firm", Academy of Management Review, Vol. 20 No. 4, pp. 986-1014.

[9]. Laari, S., Töyli, J., Solakivi, T., \& Ojala, L. (2015). SC. Journal of Cleaner Production https://doi.org/10.1016/j.jclepro.2015.06.150

[10]. Laosirihongthong, T., \& Tan, K. C. (2013). Green supply chain management practices and performance. https://doi.org/10.1108/IMDS-04-2013-0164

[11]. Min, H. and Galle, W. (2001), "Green purchasing practices of US firms", International Journal of Operations \& Production Management, Vol. 21 No. 9, pp. 1222-1238.

[12]. Rao, P. (2002), "Greening the supply chain: a new initiative in South East Asia", International Journal of Operations \& Production Management, Vol. 22 No. 6, pp. 632-655. 